\title{
INCREASING VOCABULARY BY COMPOUND WORDS MASTERY IN THE ISLAMIC BOOK “A GLIMPSE OF FAITH”
}

\author{
By \\ Fitri Rayani Siregar, M.Hum ${ }^{1}$
}

\begin{abstract}
Ada banyak cara meningkatkan kosa kata, salah satunya dengan menguasai kombinasi kata. Kombinasi kata terdiri dari 4 macam, yaitu: kombinasi 2 atau lebih kata benda, kombinasi 2 atau lebih kata kerja, kombinasi 2 atau lebih kata sifat, dan kombinasi 2 atau lebih kata keterangan. Namun, bagaimana jika kosakata yang dikuasai adalah sekitar kosakata yang berbau islami, tentu akan lebih menambah wawasan dibidang keagamaan. Terkhusus bagi penulis dan pembaca yang memang berkecimpung didunia keislaman, yaitu Fakultas Tarbiyah dan Ilmu Keguruan IAIN (Institut Agama Islam Negeri) Padangsidimpuan. Sehingga artikel ini sangat berguna untuk menambah kancah kosa kata pembaca tentang keislaman, tidak hanya terpatok pada katakata bahasa Inggris saja tetapi juga pembaca bisa menambah dan mengokohkan kosakatanya dalam bahasa Inggris keislaman yang diambil dari buku Islam "A Glimpse of Faith". Hasilnya, terdapat 85 kata tentang kombinasi kata-kata benda, 4 kata tentang kombinasi kata-kata kerja, sebuah kata tentang kombinasi kata-kata sifat, dan 6 kata tentang kombinasi kata-kata keterangan.
\end{abstract}

Keywords: Kosakata, Kombinasi Kata dan Buku Islam

\section{A. Introduction}

Word formation in morphology learns about compound word. A compound is a unit consisting of two or more bases. ${ }^{2}$ Based on Bauer, the normal way of classifying compounds is by the function they play in the sentence as nouns, verbs, adjectives, etc. ${ }^{3}$ Compounding (sometimes also called composition) rather loosely as the combination of two words to form a new word. This definition contains two crucial assumptions, the first being that compounds consist of two and not more element, the second being that these elements are words. ${ }^{4}$ As said before that compound word is two or more word that combines and become new meaning. The researcher found compound word in The Handbook of Morphology. For example:

${ }^{1}$ Fitri Rayani Siregar is Lecturer of English Education Department in Tarbiyah and Teacher Training Faculty IAIN Padangsidimpuan

${ }^{2}$ Quick and Green Baurm, Semantics and Syntactic Regularity, (Bloomington: Indiana University Press, 1977), p. 444.

${ }^{3}$ Laurie Bauer, English Word-Formation, (Cambridge: Cambridge University Press, 1983), p. 201.

${ }^{4}$ Ingo Plag, Word-Formation in English, (New York: Cambridge University Press, 2003), p. 170. 
Sneak-thief, thief is the head (a sneak-thief is a kind of thief; thief and sneak-thief are both nouns).

There some types in compound word. According to Plag, compound words are formed by types, consisting of verb+ noun example "Pickpocket", noun + noun example "Film Society", adjective +adverb example "Light-green", preposition + noun example "Afterbirth", verb + verb example "Stir-fry", verb +noun example "Brainwash", Adjective + noun example "Knee-deep", adverb + noun example "Greenhouse", and adverb + verb example "Blackmail". ${ }^{5}$ Compound words found in many case. In this case, the writer found compound words that used in the Islamic Book "The Important Lessons for the Muslim Ummah". "The Important Lessons for the Muslim Ummah" book is famous with the simple content but still in detailed explanation. That language used of the mixed of Arabic and English language.

The writer used this "The Important Lessons for the Muslim Ummah" book as the object because the compound words uniqueness here. The most of vocabulary in this book was formed from the compound words. There is some compound words is specifically use by the student in pondok pesantren, such as Islamic terms and the student daily vocabularies. There is some Islamic term which created compound words.

So, the researcher interested and make a research about compound words that found on this book. The researcher tries to prove the originality by comparing the research to the other related researches that deals with the linguistic study. There are some researchers who have conducted the study on compound words.

Based on the background of the study above, this article is dealing in increasing vocabulary by compound words mastery in islamic terms namely taken by islamic book. Compound words mastery here means the mastery and understanding about all classification of compound words. They are compound noun, compound verb, compound adjective, and compound adverb.

\footnotetext{
${ }^{5}$ Ibid., p. 183.
} 


\section{B. The Formulations of the Problem}

Based on the introduction above, the problem of the article can be formulated as follows:

1. What are islamic vocabulary in compound words dealing to increase vocabulary mastery?.

2. What kinds of compound words related to islamic vocabulary dealing to increase vocabulary mastery?

\section{Theoretical Descriptions}

\section{Vocabulary}

\section{a. Definition of Vocabulary}

Vocabulary is important aspect of language when we study in foreign language. It is one of component for the language where is vocabulary help learner in speaking and communication. Vocabulary is the stock of words on which you can draw in expressing yourself. ${ }^{6}$ Furthemore, vocabulary is groups of word should be learned as unit in conveying idea for listening, reading, writing and speaking. According Shirly Burnidge vocabulary is all the words in language list of words in lesson or books, all the word that one person knows. ${ }^{7}$

Vocabulary is one aspect that should be owned by students to make them understand and increase their aspect of language. Howard Jackson said"vocabulary is a representive collection of the words that exists in English Language. ${ }^{8}$ Then Honbry says vocabulary is all the words that person know or use, the words that people use when they are telling about particular subject. ${ }^{9}$ From defnitions above, it can be concluded that vocabulary is the total number of words that are needed to communicate ideas and express the speakers' meaning. That is the reason why it is important to learn vocabulary.

\footnotetext{
${ }^{6}$ Richard D, How to Enlarge and Improve your Vocabulary, (New York University:1994), p. 1.

${ }^{7}$ Shirly Burnidge, Oxford Basic English Dictionary, (New York:Oxford University Press, 1981), p. 447.

${ }^{8}$ Howard Jackson, Word, Meaning and Vocabulary, (London: Casell, 2000), p. 118.

${ }^{9}$ A. S. Honbry, Oxford Advanced Learner's Dictionary, (New York: Oxford University Press, 1995), p. 1506.
} 


\section{b. Kinds of vocabulary}

There are two kinds of vocabulary. The first type of vocabulary refers to the one that the students havebeen taught and that they are expected to be able to use. Meanwhile, the second one refers to the words which the students will recognize when theymeet them, but which they will probably not be able to pronounce.Haycraft, quoted by Hatch and Brown indicate two kinds of vocabulary, namely receptive vocabulary and productive vocabulary.

1) Receptive vocabulary

Receptive vocabulary can be understood only through listening and reading. Receptive vocabulary is words that learners recognize and understanding when they are used in context, but which they cannot produce. It is vocabulary that students recognize when they see or meet in reading text but do not use it in peaking and writing. Someone doesn't need to know much about the receptive vocabulary because someone rarely uses the receptive vocabulary and it is imposible for someone can understand that ideas of the utterances contextually not word by word.

2) Productive Vocabulary or Active Vocabulary

Productive vocabulary is the words that the learners understand and can pronounce correctly and use constructively in speaking and writing. It involves what is needed for receptive vocabulary plus the ability to speak or write at the appropriate time. Therefore, productive vocabulary can be addressed as an active process, because the learners can produce the words to express their thoughts to others. ${ }^{10}$

Based on the kinds of the vocabulary above receptive or passive vocabulary will be easy for understand by using listening and reading to record words or colecting vocabularies, while productive or active vocabulary will be easy understand by using concentration patterns and grammatical word in recording vocabulary. Here, the type of vocabulary used is receptive vocabulary, it is gotten by reading and understanding the context from the book "A Glimpse of Faith". 158.

${ }^{10}$ Jeremy Harmer, The Practical of English Language Teaching, (New York: Longman, 2000), p. 


\section{Compound Words}

\section{a. Definition of Compound Words}

Compounding words is the combining of two base forms together to form a new word,and other definition compounding words is show a disposition for putting words together to create a new word. Compound word processes are essential in the English language as it is possible to create new words according to certain patterns.

According to O'Grady and Dobrovolsky "Compounding is a process involving the combination of two or more roots (with or without accompanying affixes) to yield a new word. Compounding is the combination of two or more roots". 11

Ingo Plag states compounding (sometimes also call composition) rather loosely as the combination of two words to form a new word. This definition contains two crucial assumptions, the first being that compounds consist of two (and not more) elements, the second being that these elements are words. ${ }^{12}$

Then, Martin Haspelmath states, a compound is a complex lexeme that can be thought of as consisting of two or more base lexeme. In the simple case a compound consists of two lexemes that are joining together. ${ }^{13}$ So it can be concluded that compound word is combination by or more than one root, that is have a meaning.

\section{b. Compound Words Classification}

In English and other language there may be a number of different ways of classifying compounds. In compounds, the head is the elements that serve to determine both the part of speech and the semantic kind denote by the compound as a whole. Howard Jackson\& Etienne Ze Amvelastate that the

\footnotetext{
${ }^{11}$ Michael O'Grady and Dobrovolsky, Contemporary Linguistics Analysis, (Toronto: A Longman Company, 1987), p. 134-138.

${ }^{12}$ Ingo Plag, Word-formation in English, ....p. 170.

${ }^{13}$ Martin Haspelmath, Understanding Morphology, (USA: Oxford University Press, 2002), p. 85.
} 
Compound words classification, compound noun, compound verb, compound adjective, and compound adverb.

\section{1) Compound Nouns}

The second root must be noun while the first root may be a noun, a verb, an adjective or an adverb. Example of noun compounds are follows the table 1 below:

Tabel 1

Example Compound Nouns

\begin{tabular}{|c|c|c|c|}
\hline NO & $\begin{array}{l}\text { Compound } \\
\text { Noun }\end{array}$ & Examples & Meanings \\
\hline \multirow[t]{3}{*}{1} & \multirow[t]{3}{*}{ Noun + Noun } & $\begin{array}{l}\text { Muslim- } \\
\text { Majority }\end{array}$ & $\begin{array}{l}\text { Majority (population) } \\
\text { of a place is muslim. }\end{array}$ \\
\hline & & Mankind & $\begin{array}{l}\text { All human beings } \\
\text { considered together. }\end{array}$ \\
\hline & & Eid alfitr & $\begin{array}{l}\text { Observer on the first } \\
\text { day of islamic mont of } \\
\text { ramadhan, during } \\
\text { which muslim undergo } \\
\text { a priod of fasting }\end{array}$ \\
\hline 2 & Verb + Noun & $\begin{array}{l}\text { Diligently } \\
\text { Worship }\end{array}$ & $\begin{array}{l}\text { Doing worship } \\
\text { thoroughly and well. }\end{array}$ \\
\hline \multirow[t]{3}{*}{3} & \multirow[t]{3}{*}{$\begin{array}{l}\text { Adjective }+ \\
\text { Noun }\end{array}$} & Cheapskate & $\begin{array}{l}\text { Stingy person or one } \\
\text { who tries to avoid } \\
\text { paying a fair share of } \\
\text { costs or expanses. }\end{array}$ \\
\hline & & Falsehood & $\begin{array}{l}\text { The state of being } \\
\text { untrue. }\end{array}$ \\
\hline & & Wrongdoer & $\begin{array}{l}\text { A person who behaves } \\
\text { illegally or dishonestly. }\end{array}$ \\
\hline \multirow[t]{2}{*}{4} & \multirow[t]{2}{*}{$\begin{array}{l}\text { Adverb } \quad+ \\
\text { Noun }\end{array}$} & $\begin{array}{l}\text { Obligatory } \\
\text { Charity }\end{array}$ & $\begin{array}{l}\text { It from Zakah where is } \\
\text { one of the five pilars of } \\
\text { Islam }\end{array}$ \\
\hline & & Judgment day & $\begin{array}{l}\text { The time of the las } \\
\text { judgment in the end of } \\
\text { the world. }\end{array}$ \\
\hline
\end{tabular}




\section{2) Compound Verb}

The second root must be a verb and the first root may be a noun, a verb, an adjective, or an adverb. Example of verb compounds are follows the table 2 below:

Table 2

Example Compound Verb

\begin{tabular}{|c|l|c|l|}
\hline NO & \multicolumn{1}{|c|}{$\begin{array}{c}\text { Compound } \\
\text { Verb }\end{array}$} & Example & \multicolumn{1}{|c|}{ Meanings } \\
\hline 1 & Noun + Verb & Hajj trip & $\begin{array}{l}\text { An annual islamic pilgrimage to } \\
\text { mecca }\end{array}$ \\
\cline { 3 - 4 } & & God appointed & An opportunity into good works \\
\hline 2 & Verb + Verb & Slipshod & Done or doing things without care \\
\hline 3 & $\begin{array}{l}\text { Adjective } \\
\text { Verb }\end{array}$ & All owed & Halal in islam terminology. \\
\hline 4 & Adverb + Verb & over-do & To do something in a way that is too \\
\hline
\end{tabular}

3) Compound Adjective

The second root must be an adjective and the first root may be noun, an adjective, or an adverb. Verb do not combine with adjective in English. Example of verb compounds are follows the table 3 below:

Table 3

Example Adjective Compound

\begin{tabular}{|c|l|c|l|}
\hline NO & \multicolumn{1}{|c|}{$\begin{array}{l}\text { Adjective } \\
\text { Compound }\end{array}$} & Example & \multicolumn{1}{|c|}{ Meanings } \\
\hline 1 & $\begin{array}{l}\text { Noun } \\
\text { Adjective }\end{array}$ & Carefree & $\begin{array}{l}\text { Without responsibility or } \\
\text { worries. }\end{array}$ \\
\hline 2 & $\begin{array}{l}\text { Adjective + } \\
\text { Adjective }\end{array}$ & south-west & Near the southwest. \\
\hline 3 & $\begin{array}{l}\text { Adverb + } \\
\text { Adjective }\end{array}$ & Outright & $\begin{array}{l}\text { Openly and honestly without } \\
\text { hiding anything }\end{array}$ \\
\hline
\end{tabular}

4) Compound Adverb

Adverb + Adverb = Adverb Compound, Example of verb compounds are follows the table 4 below: 
Table 4

Example Adverb Compound

\begin{tabular}{|c|l|c|c|}
\hline NO & \multicolumn{1}{|c|}{$\begin{array}{c}\text { Adverb } \\
\text { Compound }\end{array}$} & Example & Meanings \\
\hline 1 & $\begin{array}{l}\text { Adverb } \\
\text { Adverb }\end{array}$ & Pass away & To go out of exixtence \\
\hline
\end{tabular}

So, the researcher takes conclusion that there are four compound words classifications, there are compound Noun, compound verb, compound adjective, and compound adverb.

\section{A Little about Islamic Book "A Glimpse of Islamic Faith"}

"A Glimpse of Islamic Faith" is a book that is written by Ghalib Ahmad Masri or most popular called by Ghalib Masri. This book is published by King Fahad National Library Cataloging in Publication Data, in Riyadh in 1996. There are 10 chapters on this book and has 89 pages. ${ }^{14}$

Then, Ghalib Ahmad Masri as the great author dedicate the book about brief explanation about islamic faith because he wants the readers knowing and understanding the straight path after reading the book. It is also because Allah has liberated man from mental bondage and train its followers to search for the truth with open minds. Allah has honoured the human mind and made it a means of discovering the tokens of his existence and glory in the universe and understanding his glorious revelation. So, how come we do not want to have the right guidance of islamic faith to Allah with all his kindness. So, that is why this book is arranged to give away and spread man to have a great guide.

\section{c. Research Methodology}

The researcher uses the descriptive qualitative method. It means that the research is based on the characteristics of phenomena and the data were analyzed using the description not numbers. It is also the content research, namely the research that is analyzed the content of the book, newpaper, novel, or articles and many others of written words. It means that the researcher only intends to describe the data

\footnotetext{
${ }^{14}$ Ghalib Ahmad Masri, A Glimpse of islamic Faith, (Riyadh: King Fahad National Library Cataloging in publication Data, 1996), p. iii.
} 
obtained as they are found in the fields. It is based on the problem statement. Here the writer gives the description of the compound words related to islamic words in written language.

Here, the writer tried to read the book first, then wrote down the compound words found, analyzed into the compound words process and gave their meanings. The writer focus only to 3 chapters on that book. They are on "Man's Need for the Correct Creed" chapter on page 8 to 10, "Monotheism in Islam" chapter on page 11 to 12, and "Religion and Human Nature (Belief in Allah)" chapter on page 13-27.

Taking those 3 chapters only are considering to the writer's limited time and chance to analyze it. The writer should coordinate, share and discuss with the experts about the result analysis to make it valid.

\section{Discussion and Conclusion}

Based on the result of the analizing done by the writer using compound noun element, the writer would like to write the conclusions of this research as the following:

1. Compound noun: there are 85 words related to compound nouns

\begin{tabular}{|c|c|c|c|}
\hline $\mathrm{NO}$ & $\begin{array}{l}\text { Compound } \\
\text { Noun }\end{array}$ & Examples & Meanings \\
\hline 1 & Noun + Noun & Islamic faith & $\begin{array}{l}\text { Muslims believe that theirs is the only } \\
\text { true faith. It is called the pillar of faith. }\end{array}$ \\
\hline 2 & & Helping people & Muslims who care each other \\
\hline 3 & & Man sense & All the human being's feeling \\
\hline 4 & & Celestial bodies & $\begin{array}{l}\text { Any natural body outside of the Earth's } \\
\text { atmosphere created by Allah }\end{array}$ \\
\hline 5 & & Solar system & $\begin{array}{l}\text { The collection of eight planets and their } \\
\text { moons in orbit around the sun, together } \\
\text { with smaller bodies in the form of } \\
\text { asteroids, meteoroids, and comets. }\end{array}$ \\
\hline 6 & & Milky way & $\begin{array}{l}\text { A Sun (a star) and all the planets around } \\
\text { it are part of a galaxy }\end{array}$ \\
\hline 7 & & Celestial masses & The mass (objects) of the planet \\
\hline 8 & & $\begin{array}{l}\text { Astronomical } \\
\text { revolution }\end{array}$ & $\begin{array}{l}\text { The movement of a planet around the } \\
\text { Sun. }\end{array}$ \\
\hline 9 & & $\begin{array}{l}\text { Broadcasting } \\
\text { stations }\end{array}$ & $\begin{array}{l}\text { A station equipped to broadcast radio or } \\
\text { television programs. }\end{array}$ \\
\hline 10 & & $\begin{array}{l}\text { Surprising } \\
\text { activities }\end{array}$ & $\begin{array}{l}\text { Something which can not think before by } \\
\text { the human being }\end{array}$ \\
\hline 11 & & Splitting process & The process that should be separated \\
\hline
\end{tabular}




\begin{tabular}{|c|c|c|c|}
\hline 12 & & Man attention & $\begin{array}{l}\text { A care of human being each other and to } \\
\text { Allah }\end{array}$ \\
\hline 13 & & Living things & All human beings considered together. \\
\hline 14 & & $\begin{array}{c}\text { Scientific } \\
\text { knowledge }\end{array}$ & $\begin{array}{l}\text { Cognizance of a fact or phenomenon } \\
\text { acquired through scientific method }\end{array}$ \\
\hline 15 & & Mankind & All human beings considered together. \\
\hline 16 & & Steam power & $\begin{array}{l}\text { Power that is applied to an engine by the } \\
\text { force of steam. }\end{array}$ \\
\hline 17 & & Water falling & $\begin{array}{l}\text { A place where water flows over a vertical } \\
\text { drop or a series of steep drops in the } \\
\text { course of a stream or river cretaed by } \\
\text { Allah }\end{array}$ \\
\hline 18 & & Future life & A life after death. \\
\hline 19 & & Human mind & $\begin{array}{l}\text { A set of cognitive faculties including } \\
\text { consciousness, perception, thinking, } \\
\text { judgement, language and memory of } \\
\text { human being. }\end{array}$ \\
\hline 20 & & Rising star & A person who is likely to be successful \\
\hline 21 & & Song birds & $\begin{array}{l}\text { A bird belonging to the clade Passeri of } \\
\text { the perching birds (Passeriformes). }\end{array}$ \\
\hline 22 & & Dead man & $\begin{array}{l}\text { The people who are having sleep so long } \\
\text { and will be awaken after world }\end{array}$ \\
\hline 23 & & Own lust & The Muslims desire and willing \\
\hline 24 & & Seen creation & $\begin{array}{l}\text { The all things which are cretaed by Allah } \\
\text { can be touched, looked, and seen. }\end{array}$ \\
\hline 25 & & Awaken man & $\begin{array}{l}\text { The new man is in process, awakening } \\
\text { through a deepening interface with the } \\
\text { world of feeling. }\end{array}$ \\
\hline 24 & Verb + Noun & Rainfall & $\begin{array}{l}\text { The quantity of rain falling within a given } \\
\text { area in a given time. }\end{array}$ \\
\hline 25 & $\begin{array}{l}\text { Adjective } \\
\text { Noun }\end{array}$ & $\begin{array}{l}\text { Two-edged } \\
\text { weapons }\end{array}$ & $\begin{array}{l}\text { Two sides of the same blade are sharp, it } \\
\text { cuts both ways. }\end{array}$ \\
\hline 26 & & Right path & Following Islamic ways \\
\hline 27 & & Straight path & Following Islamic ways \\
\hline 28 & & Main factor & The one only factor \\
\hline 29 & & Past deeds & The past actions or memories \\
\hline 30 & & Whole humanity & All people \\
\hline 31 & & Perfect attributes & Perfect things done by Muslims \\
\hline 32 & & Divine destiny & $\begin{array}{l}\text { The destini, lucky or unlucky given by } \\
\text { Allah }\end{array}$ \\
\hline 33 & & Last day & The day og judgement \\
\hline 34 & & Divine books & Holy Qoran \\
\hline 35 & & First fundamental & First based \\
\hline 36 & & Pure nature & The theoretical condition in \\
\hline
\end{tabular}




\begin{tabular}{|c|c|c|}
\hline & & $\begin{array}{l}\text { humanity would possess all that, and only } \\
\text { that, which belongs to human nature and } \\
\text { in which a person could attain to a natural } \\
\text { final end only. }\end{array}$ \\
\hline 37 & True god & The exact god, Allah \\
\hline 38 & Certain stage & The stage which is considered in Islam \\
\hline 39 & Endless question & $\begin{array}{l}\text { The last questions in the dead life or } \\
\text { grave. }\end{array}$ \\
\hline 40 & Plain fact & The common reality \\
\hline 41 & Great dimensions & All world things or dimensions \\
\hline 42 & Whole life & All life along life \\
\hline 43 & $\begin{array}{l}\text { A small part of } \\
\text { life }\end{array}$ & The smallest human being in the world \\
\hline 44 & Accurate clocks & A certain time for the judgement day \\
\hline 45 & $\begin{array}{l}\text { A million of } \\
\text { galaxies }\end{array}$ & $\begin{array}{l}\text { A million of gravitationally bound system } \\
\text { of stars, stellar remnants, interstellar gas, } \\
\text { dust, and dark matter. }\end{array}$ \\
\hline 46 & A million of stars & A million of sky's objects \\
\hline 47 & $\begin{array}{c}\text { Miraculous } \\
\text { accuracy }\end{array}$ & A certain time for the judgement day \\
\hline 48 & Unaided eyes & Directed seen or looking \\
\hline 49 & A minute kind & Virus \\
\hline 50 & $\begin{array}{l}\text { Ordinary } \\
\text { microscope }\end{array}$ & $\begin{array}{l}\text { A useful tool in the detection and } \\
\text { identification of smallest objects }\end{array}$ \\
\hline 51 & $\begin{array}{l}\text { Extraordinary } \\
\text { microscope }\end{array}$ & $\begin{array}{l}\text { A useful tool in the detection and } \\
\text { identification of an extremely smallest } \\
\text { objects }\end{array}$ \\
\hline 52 & $\begin{array}{l}\text { Multi-cellular } \\
\text { being }\end{array}$ & Amoeba \\
\hline 53 & Impregnated cell & Membrans \\
\hline 54 & Integral being & The liberal and religious muslims \\
\hline 55 & Invisible cells & Virus, or unseen or smallest objects \\
\hline 56 & $\begin{array}{l}\text { Extraordinary } \\
\text { exatitude }\end{array}$ & The quality of being precise or accurate. \\
\hline 57 & $\begin{array}{l}\text { A multi-coloured } \\
\text { fragrant }\end{array}$ & Many kinds of good smell of flowers \\
\hline 58 & Beautiful flowers & The flowers that have good seen \\
\hline 59 & Immense universe & Great life \\
\hline 60 & $\begin{array}{l}\text { Miraculous divine } \\
\text { power }\end{array}$ & The power of praying or Doa \\
\hline 61 & Marvollous secret & Allah's decisions \\
\hline 62 & Vague mystery & Allah's decisions \\
\hline 63 & Divine creation & Allah's creation \\
\hline 64 & Electric power & $\begin{array}{l}\text { The rate, per unit time, at which } \\
\text { electrical energy is transferred by an } \\
\text { electric circuit. }\end{array}$ \\
\hline 65 & Unbeatable might & Allah's decisions \\
\hline
\end{tabular}




\begin{tabular}{|c|c|c|c|}
\hline 66 & & Infinite knowedge & Unlimited knowledge \\
\hline 67 & & Limitless power & Human power that has limited side \\
\hline 68 & & Righteous nature & Allah's true names \\
\hline 69 & & Upright believer & Honest muslims \\
\hline 70 & & New experience & $\begin{array}{l}\text { The moments when the human was just } \\
\text { felt first }\end{array}$ \\
\hline 71 & & New town & Town which is the first time come \\
\hline 72 & & First time & $\begin{array}{l}\text { The time when the human was just born } \\
\text { first }\end{array}$ \\
\hline 73 & & New place & Place which is the first time come \\
\hline 74 & & Joyous colours & Colorfull colours of flowers \\
\hline 75 & & Melodious notes & Romantic context \\
\hline 76 & & Newborn baby & The baby was just born \\
\hline 77 & & Absolute power & $\begin{array}{l}\text { The exact god, Allah is the exact power } \\
\text { of human }\end{array}$ \\
\hline 78 & & Real meaning & Islam as the fact meaning in life \\
\hline 79 & & Rightful god & The exact god, Allah \\
\hline 80 & Adverb + Noun & Underground & Grave \\
\hline 81 & & $\begin{array}{l}\text { Extremely minute } \\
\text { living cell }\end{array}$ & Virus \\
\hline 82 & & Highly tasks & $\begin{array}{l}\text { The responsibles of human or Muslims in } \\
\text { the world }\end{array}$ \\
\hline 83 & & $\begin{array}{l}\text { Highly wonderful } \\
\text { tasks }\end{array}$ & $\begin{array}{l}\text { The responsibles of human or Muslims in } \\
\text { the world }\end{array}$ \\
\hline 84 & & Deadly desease & $\begin{array}{l}\text { The sickness that can make human being } \\
\text { dead }\end{array}$ \\
\hline 85 & & Worldly comforts & After life \\
\hline
\end{tabular}

2. Compound verb; there are 4 compound verbs found.

\begin{tabular}{|c|l|l|l|}
\hline NO & $\begin{array}{l}\text { Compound } \\
\text { Verb }\end{array}$ & \multicolumn{1}{|c|}{ Example } & \multicolumn{1}{|c|}{ Meanings } \\
\hline 1. & $\begin{array}{l}\text { Noun } \\
\text { Verb }\end{array}$ & 1. Man Owed & $\begin{array}{l}\text { Man's promises to Allah since she/ } \\
\text { he is in his/ her mother's belly }\end{array}$ \\
\cline { 3 - 4 } & & $\begin{array}{l}\text { 2. God } \\
\text { promised } \\
\text { 3. Upright } \\
\text { believe }\end{array}$ & $\begin{array}{l}\text { The things that Allah promises as } \\
\text { Muslims' right }\end{array}$ \\
\hline & & $\begin{array}{l}\text { Two things which have to done and } \\
\text { felt by Muslims about Allah. }\end{array}$ \\
\hline
\end{tabular}


3. Compound adjective; there is a word found related to compound adjective on the book.

\begin{tabular}{|c|l|c|l|}
\hline NO & $\begin{array}{l}\text { Compound } \\
\text { adjective }\end{array}$ & Example & \multicolumn{1}{|c|}{ Meanings } \\
\hline 1. & $\begin{array}{l}\text { Adjective }+ \\
\text { adjective }\end{array}$ & Right handed & $\begin{array}{l}\text { The people who works using right } \\
\text { sides/ hands. }\end{array}$ \\
\hline
\end{tabular}

4. Compound adverb: there are 6 words realted to compound adverb on the book.

\begin{tabular}{|c|c|c|c|}
\hline $\mathrm{NO}$ & $\begin{array}{c}\text { Adverb } \\
\text { Compound }\end{array}$ & Example & Meanings \\
\hline 1 & \multirow[t]{6}{*}{$\begin{array}{ll}\text { Verb } & + \\
\text { Adverb } & \end{array}$} & Drive away & $\begin{array}{l}\text { To get free or take out satan from the } \\
\text { body }\end{array}$ \\
\hline 2 & & Far away & Go far, so far from Allah \\
\hline 3 & & Go astray & Get lose from Islamic way \\
\hline 4 & & Go away & Go far, so far from Allah \\
\hline 5 & & Run away & Go far, so far from Allah \\
\hline 6 & & Turn back & Back to Allah side \\
\hline
\end{tabular}

\section{E. Suggestion}

Considering the importance of understanding the words forms especially in the study of compound word, some suggestions are made. For students who are willing to conduct a research on the same topic, it will hopefully give a clear understanding in analyzing islamic vocabulary using the syntactical study namely in compound words. It is also hoped that there are other students or readers who will conduct study on related topic from different angle, hoping that there will be new findings dealing with syntactical study. Finally, the writer hopes that this article can be used as reference for those who are interested in studying syntactical study. 


\section{REFERENCES}

Bauer, Laurie. 1983. English Word-Formation. Cambridge: Cambridge University Press.

Burnidge, Shirly. 1981. Oxford Basic English Dictionary. New York:Oxford University Press.

Harmer, Jeremy. 2000. The Practical of English Language Teaching. New York: Longman.

Haspelmath, Martin. 2002. Understanding Morphology. USA: Oxford University Press.

Honbry, A. S. 1995. Oxford Advanced Learner's Dictionary. New York: Oxford University Press.

Jackson, Howard. 2000. Word, Meaning and Vocabulary. London: Casell.

Martin J. R. 1992. English Text: System and Structure. Amsterdam: Jhon Benjamins Publishing Company.

Masri, Ghalib Ahmad. 1996. A Glimpse of islamic Faith. Riyadh: King Fahad National Library Cataloging in publication Data.

O’Grady W., \& Dobrovolsky M. 2000. Contemporary Linguistics Analysis. Toronto: Coop Clark Ltd.

O’Grady, Micheal \& Dobrovolsky. 1987. Contemporary Linguistics Analysis. Toronto: A Longman Company.

Plag, Plag. 2003. Word-Formation in English. New York: Cambridge University Press.

Redman, Stuart. 2001. English Vocabulary in Use: Pre-Intermediate \& Intermediate. Jakarta: Penerbit Erlangga.

Quick \& Green Baurm. 1977. Semantics and Syntactic Regularity. Bloomington: Indiana University Press.

Richard, D. 1994. How to Enlarge and Improve your Vocabulary. New York University. 